\title{
Vitamin C: a misunderstood ally?
}

\author{
Jiajia Ren, Xuting Jin, Ya Gao, Ruohan Li, Jiamei Li, Jingjing Zhang, Xiaochuang Wang and Gang Wang*
}

As an important antioxidant, vitamin $\mathrm{C}$ deficiency has frequently been observed in critically ill patients [1]. The treatment with early high-dose intravenous vitamin $C$ has shown beneficial effects on patients with sepsis, septic shock, and myocardial ischemia in both preclinical and clinical studies [2]. Recently, 2 original articles caught my attention. In December 2019, a nationwide cohort study involving 2713 patients reported in Critical Care demonstrated that high-dose vitamin $\mathrm{C}$ therapy was associated with reduced mortality in patients with severe burns [3]. The pleiotropic effects of vitamin $\mathrm{C}$ may result from its protection against oxidative stress-mediated cell damage and organ dysfunction [1]. However, the CITRIS-ALI trial, reported earlier by Fowler and colleagues in JAMA, October 2019, showed an inconsistent result. In this study, 167 adults with sepsis and acute respiratory distress syndrome were randomized to receive either high-dose vitamin $\mathrm{C}$ or placebo for $96 \mathrm{~h}$, and the primary outcomes including modified Sequential Organ Failure Assessment (mSOFA) scores were not statistically different between the groups [4], despite the expected protective effects of vitamin $\mathrm{C}$ against multiple organ failure, inflammation, and endothelial injury as shown in their phase I safety trial [5].

After scrutinizing the results in the CITRIS-ALI trial, we proposed that a survivorship bias may have contributed to the conflicting result. As we noted from their results (Fig. 3, page 1268), there were sudden increases in the overall mortality probability from day 0 to day 7 in the placebo group. Thus, we performed further analyses according to Fig. 3 and discovered that the overall mortalities in the placebo group had more intensive increases on day 2 (10.8 vs. $1.2 \% ; P=0.021)$, day $3(14.5$ vs. $2.4 \% ; P=0.005)$, and day $4(19.3$ vs. $3.6 \% ; P=0.001)$ than those in the vitamin $C$ group (shown in Table 1). Those sudden increases in mortality in the placebo group may result from the deteriorated conditions of certain patients, leaving the survived patients with less severe conditions for statistical analyses at the primary end points. Therefore, when the mSOFA at $96 \mathrm{~h}$ and the levels of $\mathrm{C}$-reactive protein and thrombomodulin at $168 \mathrm{~h}$ were evaluated, the survivorship bias rendered the differences between the vitamin $\mathrm{C}$ group and placebo group uncomparable, causing decreased reliability of the results. Nevertheless, a positive effect of vitamin $\mathrm{C}$ still gleams behind the results presented, as a misunderstood ally.

\section{Abbreviations}

mSOFA scores: Modified Sequential Organ Failure Assessment scores

\section{Acknowledgements \\ Not applicable.}

\section{Authors' contributions}

$J R, X J, Y G, R L, J L, J Z$, and $X W$ performed the analyses and interpreted the results. JR and $X J$ wrote the manuscript. $X J, Y G, R L, J L, J Z$, and $X W$ revised the manuscript. GW raised the hypothesis and supervised the work. All authors read and approved the final manuscript.

\section{Funding}

This work was supported by the National Natural Science Foundation of China (No. 81770057).

\section{Availability of data and materials}

Not applicable.

\section{Ethics approval and consent to participate} Not applicable.

\footnotetext{
* Correspondence: gang_wang@xjtu.edu.cn

Department of Critical Care Medicine, The Second Affiliated Hospital of Xi'an Jiaotong University, Xi'an 710004, Shaanxi Province, China
}

(c) The Author(s). 2020 Open Access This article is distributed under the terms of the Creative Commons Attribution 4.0 International License (http://creativecommons.org/licenses/by/4.0/), which permits unrestricted use, distribution, and reproduction in any medium, provided you give appropriate credit to the original author(s) and the source, provide a link to the Creative Commons license, and indicate if changes were made. The Creative Commons Public Domain Dedication waiver (http://creativecommons.org/publicdomain/zero/1.0/) applies to the data made available in this article, unless otherwise stated. 
Table 1 A rough estimate of mortalities from day 0 to day 7

\begin{tabular}{lllllllll}
\hline Day & & 1 & 2 & 3 & 4 & 5 & 6 & 7 \\
\hline Placebo $(n=83)$ & No. at risk & 82 & 74 & 71 & 67 & 64 & 61 & 59 \\
& Mortality (\%) & $1(1.2)$ & $9(10.8)$ & $12(14.5)$ & $16(19.3)$ & $19(22.9)$ & $22(26.5)$ & $24(28.9)$ \\
Vitamin C $(n=84)$ & No. at risk & 84 & 83 & 82 & 81 & 80 & 78 & 74 \\
& Mortality (\%) & $0(0)$ & $1(1.2)$ & $2(2.4)$ & $3(3.6)$ & $4(4.8)$ & $6(7.1)$ & $10(11.9)$
\end{tabular}

The overall mortalities in the placebo group had more intensive increases on day 2 (10.8 vs. $1.2 \% ; P=0.021)$, day 3 (14.5 vs. $2.4 \%$; $P=0.005)$, and day 4 (19.3 vs.

$3.6 \% ; P=0.001$ ) compared with those in the vitamin $C$ group

\section{Consent for publication}

Not applicable.

\section{Competing interests}

The authors declare that they have no competing interests.

Received: 11 December 2019 Accepted: 1 January 2020

Published online: 07 January 2020

\section{References}

1. Spoelstra-de Man AME, Elbers PWG, Oudemans-van Straaten HM. Making sense of early high-dose intravenous vitamin C in ischemia/reperfusion injury. Crit Care. 2018;22(1):70.

2. Li J. Evidence is stronger than you think: a meta-analysis of vitamin C use in patients with sepsis. Crit Care. 2018;22(1):258.

3. Nakajima M, Kojiro M, Aso S, Matsui H, Fushimi K, Kaita Y, Goto H, Yamaguchi Y, Yasunaga H. Effect of high-dose vitamin C therapy on severe burn patients: a nationwide cohort study. Crit Care. 2019;23(1):407.

4. Fowler AA 3rd, Truwit JD, Hite RD, Morris PE, DeWilde C, Priday A, Fisher B, Thacker LR 2nd, Natarajan R, Brophy DF, et al. Effect of vitamin C infusion on organ failure and biomarkers of inflammation and vascular injury in patients with sepsis and severe acute respiratory failure: the CITRIS-ALI randomized clinical trial. Jama. 2019:322(13):1261-70.

5. Fowler AA 3rd, Syed AA, Knowlson S, Sculthorpe R, Farthing D, DeWilde C, Farthing CA, Larus TL, Martin E, Brophy DF, et al. Phase I safety trial of intravenous ascorbic acid in patients with severe sepsis. J Transl Med. 2014;12:32.

\section{Publisher's Note}

Springer Nature remains neutral with regard to jurisdictional claims in published maps and institutional affiliations. 